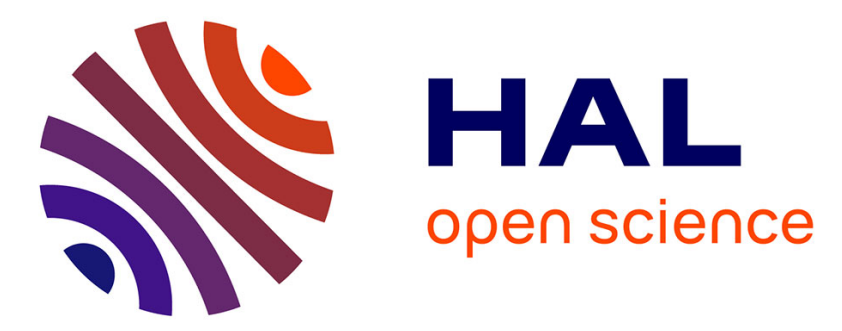

\title{
Standardized protocol to evaluate pollen polypeptides as bee food source
}

\author{
Maryse Vanderplanck, Baptiste Leroy, Bernard Wathelet, Ruddy Wattiez, \\ Denis Michez
}

\section{- To cite this version:}

Maryse Vanderplanck, Baptiste Leroy, Bernard Wathelet, Ruddy Wattiez, Denis Michez. Standardized protocol to evaluate pollen polypeptides as bee food source. Apidologie, 2014, 45 (2), pp.192-204. 10.1007/s13592-013-0239-0 . hal-01234716

\section{HAL Id: hal-01234716 \\ https://hal.science/hal-01234716}

Submitted on 27 Nov 2015

HAL is a multi-disciplinary open access archive for the deposit and dissemination of scientific research documents, whether they are published or not. The documents may come from teaching and research institutions in France or abroad, or from public or private research centers.
L'archive ouverte pluridisciplinaire HAL, est destinée au dépôt et à la diffusion de documents scientifiques de niveau recherche, publiés ou non, émanant des établissements d'enseignement et de recherche français ou étrangers, des laboratoires publics ou privés. 


\title{
Standardized protocol to evaluate pollen polypeptides as bee food source
}

\author{
Maryse VANDERPlanck ${ }^{1}$, Baptiste Leroy ${ }^{2}$, Bernard WATHELET ${ }^{3}$, Ruddy WATtiez ${ }^{2}$, \\ Denis Michez ${ }^{1}$
}

\footnotetext{
${ }^{1}$ Research Institute of Biosciences, Laboratory of Zoology, University of Mons-UMONS, Place du parc 20, 7000 Mons, Belgium

${ }^{2}$ Research Institute of Biosciences, Department of Proteomic and Microbiology, University of Mons-UMONS, Place du parc 20, 7000 Mons, Belgium

${ }^{3}$ Industrial Biological Chemistry Unit, University of Liège, Gembloux Agro-Bio Tech, Passage des Déportés 2 , Gembloux, 5030 Liège, Belgium
}

Received 27 January 2013 - Revised 7 August 2013 - Accepted 3 September 2013

\begin{abstract}
Bees mainly rely on pollen for their protein resources. As these molecules are essential for numerous aspects of bee physiology like ovary development and larval growth, their quantification and determination are crucial to evaluate diet quality. However, the term "protein" has been used to mention crude protein, total amino acids, or protein sensu stricto (i.e., polypeptides of molecular weight $>10,000 \mathrm{Da}$ ). In addition to this ambiguity, current methods for protein quantification suffer from bias due to nonprotein nitrogen and protein-to-protein variations. A reliable and nondestructive method to quantify the pollen polypeptides is then essential to estimate bee food source. The present paper aims (a) to detail such a protocol, (b) to evaluate its efficiency, and (c) to confront its results to those returned by traditional methods of protein estimation. Our protocol clearly overrides some bias of previous methods and is highly reliable. Results show the high variability in content of pollen polypeptides and suggest that the main part of the proteinaceous nitrogen is from oligopeptides. They also highlight that hand-collected pollen is a better matrice than pollen loads to estimate the polypeptides of pollen as bee food source.
\end{abstract}

pollen / polypeptide extraction / BCA assay / nutritive value

\section{INTRODUCTION}

As bees exclusively forage on floral rewards, pollen constitutes the prime protein resource for both adults and larvae (Michener 2007). Quality and quantity of pollen protein are known to impact on bees as (a) ten amino acids are essential (De Groot 1953), (b) bees do not forage on equal amounts of pollen according to protein concentration (Roulston and Cane 2002), (c) honeybees prefer nectar that contains

Corresponding author: M. Vanderplanck, maryse.vanderplanck@umons.ac.be

Manuscript editor: Yves Le Conte amino acids (Alm et al. 1990), and (d) high protein concentration in food can increase longevity, body size, ovary development, and larval growth (Knox et al. 1971; Tasei and Aupinel 2008; Quezada-Euan et al. 2011). Pollen protein content is highly variable among plant species: "crude protein content" (based on nitrogen measure) ranging from 2.5 to $61 \%$ of dry mass (Buchmann 1986) and "protein-bound amino acid" (including oligo- and polypeptides) from 3.5 to $24.9 \%$ (Weiner et al. 2010). This variability in protein content among different plant species implies that pollen does not represent a universally suitable resource. Accurate definition and quantification of pollen pro- 
teins therefore appear to be very important in two main research axes: (a) beekeeping management and wild bee conservation (Herbert et al. 1977; Feuillet et al. 2008; Brodschneider and Crailsheim 2010) and (b) evolutionary biology of beehost plant interactions (Weiner et al. 2010; Sedivy et al. 2011).

The general terms "total amino acids" and "proteins" refer to diverse molecules and functions. On one hand, total amino acids include free amino acids and protein-bound amino acids. Whereas free amino acids can be modified in nonprotein analogs which are toxic for bees (Huang et al. 2011), protein-bound amino acids constitute the usable part of the total amino acids in pollen (including the essential amino acids; Cohen 2004). Previous studies demonstrated that bumblebees can select pollen of high protein concentration (Robertson et al. 1999; Hanley et al. 2008; Kitaoka and Nieh 2009; Leonhardt and Blüthgen 2012), possibly based on perception and learning of particular volatile compounds (Dobson et al. 1999; Schmidt and Hanna 2006). Moreover, although Pernal and Currie (2002) have stated that the use of oral or alimentary receptors to rapidly assess pollen quality is improbable, Whitehead and Larsen (1976) suggested that gustatory sensilla on the mouth parts of honeybee may be responsive to proteins or amino acids (de Brito Sanchez 2011 and references therein). On the other hand, proteins (i.e., protein-bound amino acids) include oligopeptides (molecular weight $<10,000 \mathrm{Da}$ ) and polypeptides (molecular weight $>10,000 \mathrm{Da}$ ). As far as known, dietary oligopeptides do not show particular physiological function while polypeptide quantity and quality can enhance immune functions in insects (Lee et al. 2006, 2008). The functional roles of polypeptides in insect diets also include binding fats, binding flavors (i.e., proteins have little flavor of their own, but influence flavor perception via binding and/or adsorption of flavor compounds), and storage (Cohen 2004). They may act as emulsifiers and may give the diet greater elasticity or other texture features that may be either desirable or detrimental. They also increase diet viscosity and help diet to retain a given shape. Moreover, polypeptides include enzymes that may impact the nutritional value of diets, including the destruction of nutrients such as lipids and other polypeptides or the formation of insoluble or indigestible complexes (Cohen 2004).

Quantification and determination of free and total amino acids of pollen are well documented and quite similar in literature (Somerville and Nicol 2006; Weiner et al. 2010). However, evaluation of protein-bound amino acids is not standardized in definition and analysis (extraction and quantification) leading to unequal information (Hartfelder et al. 2013). The term "protein" was used to mention crude protein, total amino acids, or polypeptides, but amounts are not equal. Crude proteins correspond to the total nitrogen content (including nonprotein nitrogen) converted to protein by using a conversion factor (see below) (Standifer 1967; Roulston and Cane 2000; Somerville and Nicol2006). Total amino acids include free amino acids and proteinbound amino acids (Weiner et al. 2010), whereas the distinction between polypeptides (molecular weight $>10,000 \mathrm{Da}$ ) and oligopeptides (molecular weight $<10,000 \mathrm{Da}$ ) is never considered in the literature about bee diet. In the present paper, we consider the term protein in its strict definition, namely polypeptides of molecular weight $>10,000$ Da.

Current methodologies for protein quantification include two common assays: (a) colorimetric assays based on direct protein detection and quantification (e.g., Bradford assay using Coomassie blue coloration) (De Sá-Otero et al. 2009) and (b) the micro-Kjeldahl assay which is based on total nitrogen measurement to evaluate the protein content indirectly by using a nitrogen-protein conversion factor (Standifer et al. 1980; Somerville and Nicol 2006; Forcone et al. 2011). These techniques suffer from considerable limits. Indeed, the Coomassie blue coloration depends on the amino acid composition of the proteins, generating high protein-toprotein variation and bias in quantification (e.g., proteins with low arginine content will be underestimated) (Kruger 2002). Moreover, since protein quantifications are made by comparison 
with one specific protein used as standard [usually bovine serum albumin (BSA) or bovine gamma globulin (BGG)], the nature of this polypeptide is very important especially in terms of the sensitivity and variability which could hinder analysis of unknown proteic mixes (e.g., pollen). Although traditional methods such as micro-Kjeldahl or Dumas show minimal protein-to-protein variation, they are based on nitrogen quantification including additional nonprotein nitrogen sources such as free amino acids, oligopeptides, or alkaloids, generating overestimations (Detzel and Wink 1993; Moore et al. 2010). Furthermore, these methods require a large amount of pollen (minimum $50 \mathrm{mg}$, Bremner and Mulvaney 1982) only easily available from honeybee pollen loads. The study of protein from pollen loads shows methodological problems because of the variable amount of nectar added by the honeybee workers to make the load (Roulston and Cane 2000).

The aim of this paper is to adapt and validate a nondestructive method for polypeptide (molecular weight $>10,000 \mathrm{Da}$ ) extraction and quantification from very low amounts of handcollected pollen $(\sim 5 \mathrm{mg})$ and honeybee pollen loads. We then confront our results to those returned by the most commonly used methods, namely Kjeldahl analysis, amino acids analysis, and Bradford assay.

\section{MATERIAL AND METHODS}

\subsection{Material}

Methods of protein quantification were tested on pollen from various origins: (a) hand-collected pollen from Actinidia deliciosa, Aster tripolium, Calluna vulgaris, Cytisus scoparius, Hedera helix, Helianthus annuus, Impatiens glandulifera, Medicago sativa, and Salix caprea and (b) honeybee pollen loads from $A$. deliciosa $^{\dagger}$, A. tripolium, Asteraceae sp., C. vulgaris $^{\dagger}$,

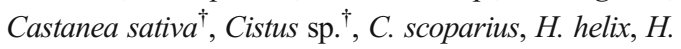
annuus, I. glandulifera, M. sativa, Prunus sp. ${ }^{\dagger}$, Rubus sp. ${ }^{\dagger}$, S. caprea, and Sorbus aucuparia $\left[{ }^{\dagger}=\right.$ pollen loads from commercial blends (Ruchers de Lorraine, France); other pollen loads from the authors' honeybee hives]. Pollen samples from commercial blends were obtained from a single blend for each plant. All samples were carefully homogenized before analyses. The floral composition of pollen loads was checked under a light microscope (Leitz) at magnification of $\times 400$ or $\times 1,000$. We analyzed for each pollen sample three aliquots except for hand-collected pollen from C. scoparius $(n=2)$.

\subsection{Protein content analysis}

\subsubsection{Extraction and quantification of polypeptide content}

Pollen grain is an extremely durable structure, difficult to disrupt, and resistant to chemical attack (strong acids, bases, and solvents) (Vanderplanck et al. 2011; Odoux et al. 2012). For efficient nondestructive extraction, we adapted the protocol for recalcitrant plant tissues from Wang et al. (2006). The methodology is synthesized in Figure 1.

For each extraction, $5 \mathrm{mg}$ of lyophilized pollen was weighed into a 2-mL tube. Equivalent volume of glass beads was added into the tube, and the pollen was ground into a fine powder by bead beating to remove further contaminants and extract the polypeptides. This operation was repeated five times under liquid nitrogen to minimize proteolysis.

The pollen disruption was followed by three washes performed at $4{ }^{\circ} \mathrm{C}$ successively with (a) $10 \%$ TCA/acetone, (b) $80 \%$ methanol $(v / v), 0.1 \mathrm{M}$ ammonium acetate, and (c) $80 \%$ acetone. For each washing step, the insoluble material was collected by centrifugation at $16,000 \times g$ for $3 \mathrm{~min}$ at $4{ }^{\circ} \mathrm{C}$, and the supernatant was discarded. Sonication was performed during all washes to a full dispersal of pollen. The final pellet was submitted to incubation at $50{ }^{\circ} \mathrm{C}$ for at least $10 \mathrm{~min}$ to remove residual acetone.

Next, a phenol/Sodium Dodecyl Sulfate (SDS) combining procedure was used to extract proteins from dry residual pellets. First, $500 \mu \mathrm{L}$ of SDS buffer $(0.1 \mathrm{M}$ Tris- $\mathrm{HCl}, \mathrm{pH} 8.0,30 \%(w / v)$ sucrose, $5 \%(v /$ v) 2-mercaptoethanol, and $2 \%(w / v)$ SDS) was added to the pellets then vortexed and sonicated at $4{ }^{\circ} \mathrm{C}$ for $10 \mathrm{~min}$. Five hundred microliters of Tris-buffered phenol ( $\mathrm{pH}$ 8.0) was then added to the sample. After vortexing and incubation for $10 \mathrm{~min}$ under agitation, the phenolic phase was recovered by centrifugation at $16,000 \times g$ for $10 \mathrm{~min}$ at $4{ }^{\circ} \mathrm{C}$. The upper phenol phase $(400 \mu \mathrm{L})$ was harvested, and $1.6 \mathrm{~mL}$ of $0.1 \mathrm{M}$ 


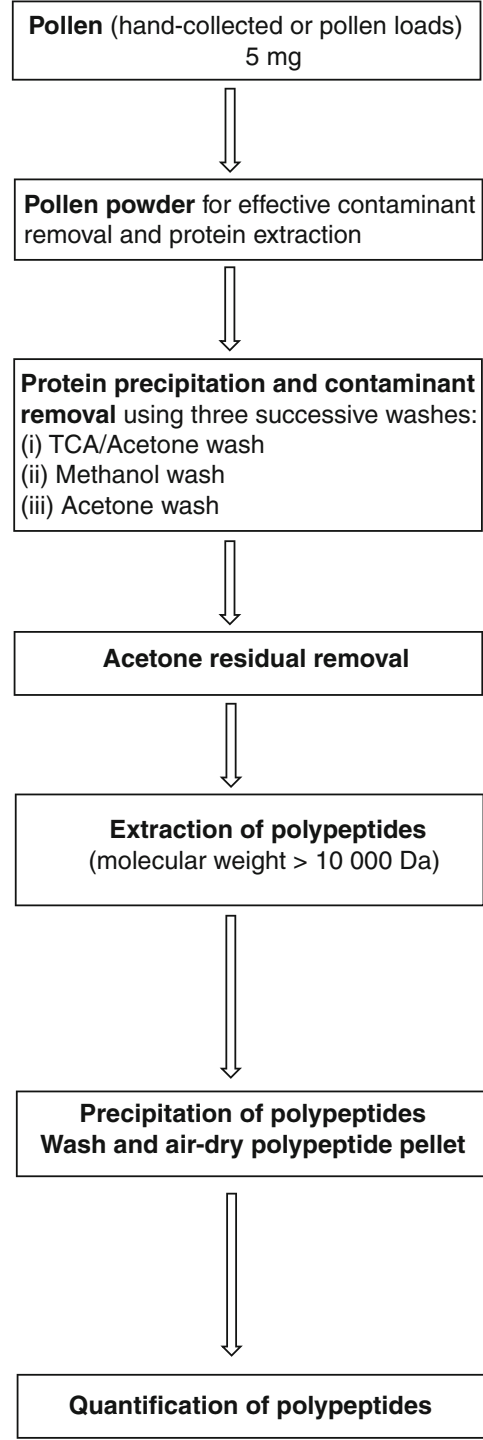

Grind into a fine powder by bead beating under liquid nitrogen

Fill the tube wih (i) $10 \%$ TCA/acetone, (ii) $80 \%$ methanol plus $0.1 \mathrm{M}$ ammonium acetate, and (iii) $80 \%$ acetone For each washing step: Sonicate the tube to full a dispersal of pollen Centrifuge at $16000 \mathrm{~g}$ for $3 \min \left(4^{\circ} \mathrm{C}\right)$ Discard the supernatant

Incubate at $50^{\circ} \mathrm{C}$ for at least $10 \mathrm{~min}$

(i) Add $500 \mu$ of SDS buffer (0.1 M Tris- $\mathrm{HCl}$ pH 8.0, $30 \%(w / v)$ sucrose, $5 \%(v / v)$ 2-mercaptoethanol, $2 \%(w / v) S D S)$

Mix and sonicate at $4^{\circ} \mathrm{C}$ for 10 minutes. (ii) Add $500 \mu$ l of Tris-buffered phenol (pH 8.0). Mix and incubate for 10 minutes at RT under agitation Centrifuge at $16000 \mathrm{~g}$ for 10 minutes at $4{ }^{\circ} \mathrm{C}$ and recover $400 \mu$ lof the upper phenol phase.

Fill the tube wih $0.1 \mathrm{M}$ ammonium acetate methanolic solution and incubate at $-20^{\circ} \mathrm{C}$ overnight Centrifuge at $16000 \mathrm{~g}$ for $10 \mathrm{~min}\left(4^{\circ} \mathrm{C}\right)$ and discard the supernatant

Wash the pellet once with ice-cold $100 \%$ methanol and once with ice-cold $80 \%$ acetone (mix and centrifuge as above)

Allow the polypeptides to air dry briefly Dissolve the polypeptides in a $4 \mathrm{M}$ guanidine. $\mathrm{HCl}$ solution ( $\mathrm{pH}$ 8.5)

Figure 1. Flowchart of protein extraction protocol.

ammonium acetate methanolic solution was added and incubated at $-20{ }^{\circ} \mathrm{C}$ overnight. Precipitated polypeptides were then recovered by centrifugation at $16,000 \times \mathrm{g}$ and $4{ }^{\circ} \mathrm{C}$ for $10 \mathrm{~min}$. The obtained pellets were washed once with ice-cold $100 \%$ methanol and once with ice-cold $80 \%$ acetone. For each washing step, tubes were centrifuged at $16,000 \times \mathrm{g}$ for $3 \mathrm{~min}$ at $4{ }^{\circ} \mathrm{C}$. Then, the supernatant was carefully removed using a pipette and discarded.
Finally, the washed polypeptide pellet was air dried briefly and dissolved in a $4 \mathrm{M}$ guanidine $/ \mathrm{HCl}$ solution ( $\mathrm{pH}$ 8.5).

Quantifications of total polypeptide were performed using bicinchoninic acid (BCA) Protein Assay Kit (Pierce, Thermo Scientific). The BCA method combines the reduction of $\mathrm{Cu}^{+2}$ to $\mathrm{Cu}^{+1}$ by protein in an alkaline medium (biuret reaction) with a colorimetric detection of the cuprous cation $\left(\mathrm{Cu}^{+1}\right)$ using a reagent 
containing BCA. The chelation of two molecules of BCA with one cuprous ion formed a purple-colored reaction product exhibiting a strong absorbance at $562 \mathrm{~nm}$. The polypeptide concentrations are determined, based on a standard curve of a series of dilutions of BSA. The standard curve is nearly linear with increasing protein concentrations over a broad working range $(20-2,000 \mu \mathrm{g} / \mathrm{mL}$ ), but a four-parameter (quadratic) curve will provide more accurate results than a linear fit. The curve is described by the following equation: $y=$ bottom $+($ top-bottom $) /(1+$ $10^{\wedge}((\log (\operatorname{EC} 50)-\log (x)) \times$ slope $\left.)\right)$, in which $x$ represents the concentration of polypeptides (micrograms per milliliter) and $y$ represents the absorbance at $560 \mathrm{~nm}$ (O.D. unit). The top and bottom plateaus of the curve are in the same units as $y$, and slope represents the slope of the curve. This BCA method is compatible with many interfering agents such as guanidine/ $\mathrm{HCl}(\leq 4 \mathrm{M})$ and displays a low protein-to-protein variation (coefficient variation $=14.7 \%$, provided in BCA Protein Assay Kit instructions, Pierce, Thermo Scientific).

\subsubsection{Repeatability of the method}

To assess the efficiency of pollen grain disruption, we determined the proportion of broken grains. The pollen grains were recovered after phenol extraction and embedded in glycerine gelatine on a slide. The percentages of disrupted pollen grains were estimated by counting the grains along three lines chosen randomly across the cover slip at a magnification of $\times 400$ by the light microscope (Leitz).

The entire extraction process was repeated 15 times on a commercial blend of willow pollen loads (Salix sp.) to measure global variability in extraction and polypeptide quantification. The lyophilized pollen was firstly homogenized and divided into three batches. Each batch was then divided into five equal aliquots, which were processed separately (Table I). For each aliquot, the extracted polypeptides were quantified in triplicate.

The recovery rate of polypeptides was calculated using BGG at a concentration of $1 \mathrm{mg} / \mathrm{mL}$. Polypeptide concentration was compared before and after phenolic

Table I. Repeatability and efficiency of the phenolic extraction and BCA quantification for pollen polypeptides of $S$. caprea.

\begin{tabular}{llllll}
\hline Batch & Aliquot & Pollen weight $(\mathrm{mg})$ & $\begin{array}{l}\text { Polypeptides } \\
\text { content }(\mu \mathrm{g} / \mathrm{mg})\end{array}$ & $\begin{array}{l}\text { CV BCA } \\
\text { assay }(\%)^{\mathrm{a}}\end{array}$ & CV extraction (\%) $^{\mathrm{b}}$ \\
\hline Batch A & Aliquot A.1 & 5.68 & 118.58 & 1.87 & 5.03 \\
& Aliquot A.2 & 5.57 & 105.46 & 3.99 & \\
& Aliquot A.3 & 5.17 & 114.56 & 15.20 & \\
& Aliquot A.4 & 4.74 & 113.45 & 11.71 & \\
& Aliquot A.5 & 5.32 & 106.33 & 9.41 & \\
Batch B & Aliquot B.1 & 5.12 & 102.79 & 3.10 & \\
& Aliquot B.2 & 5.54 & 105.07 & 8.66 & \\
& Aliquot B.3 & 5.41 & 100.47 & 1.91 & \\
& Aliquot B.4 & 4.62 & 113.74 & 10.34 & \\
& Aliquot B.5 & 5.58 & 99.93 & 4.45 & \\
Batch C & Aliquot C.1 & 5 & 115.55 & 14.13 & \\
& Aliquot C.2 & 5 & 110.94 & 9.15 & \\
& Aliquot C.3 & 4.67 & 119.55 & 9.49 & \\
& Aliquot C.4 & 5.59 & 109.15 & 3.51 & \\
& Aliquot C.5 & 4 & 132.31 & 4.42 & \\
\hline
\end{tabular}

\footnotetext{
${ }^{a}$ Variability of the polypeptide quantification for each aliquot (three assays per aliquot) expressed by the coefficient of variation (percent)

${ }^{\mathrm{b}}$ Variability of the polypeptide extraction for each batch (five aliquots per batch) expressed by the coefficient of variation (percent)
} 
extraction using BCA assay. In the same way, the recovery rate of oligopeptides was determined using BGG $(500 \mathrm{mg} / \mathrm{mL})$ after carbamidomethylation of cysteines and tryptic digestion. The sample solution was split into two equal aliquots that were lyophilized. One of them was extracted as previously described (phenolic extraction). The two lyophilized aliquots were solubilized in a mixture of $\alpha$-cyano-4-hydroxycinnamic acid matrix (20 mg/mL in $70 \%$ acetonitrile, $1.5 \% \mathrm{FA})$ and 2,3-dihydroxybenzoic acid $(20 \mathrm{mg} / \mathrm{mL}$ in $70 \%$ acetonitrile, $0.03 \%$ TFA) $(75: 25, v / v)$. A total of $40 \mu \mathrm{L}$ was added and spots were applied onto a 96 target well plate $(2 \mu \mathrm{L}$ per spot). Analyses were performed on a Matrix Assisted Laser Desorption Ionization-Time of Flight (MALDI-TOF) mass spectrometer (Bruker). The spectra were acquired in the positive linear mode by ten subspectral accumulations with $15 \mathrm{kV}$ of source voltage and $960 \mathrm{~V}$ of pulse voltage.

\subsection{Kjeldahl and Bradford methods}

We confronted results of the above-described methodology with the two current protein measurements in pollen (Kjeldahl and Bradford assays) (Table II). Because the Kjeldahl method requires large amounts of pollen ( $5 \mathrm{~g})$, assays were performed on ten pollen samples available in sufficient amount: Asteraceae sp., A. deliciosa, C. vulgaris, C. sativa, Cistus sp., C. scoparius, Prunus sp., Rubus sp., S. caprea, and S. aucuparia (Table II).

Kjeldahl assays were conducted by the Experimental Unit for Alternative Husbandry and Health of Monogastric (INRA, Surgères, France) according the NF EN ISO 5983-2 norm. This method is based on the mineralization of the pollen sample in $\mathrm{H}_{2} \mathrm{SO}_{4}$ with a catalyst. The mineralized product is then neutralized and distilled. The pollen nitrogen released in a mineral form is assayed, and the total protein is estimated as 6.25 times the nitrogen content.

Bradford protein assays (kit, Bio-Rad Protein Assay) were performed on the same polypeptide extraction as the BCA assay, avoiding the extraction bias. The procedure involves the addition of an acidic dye to a protein solution (Coomassie ${ }^{\circledR}$ Brilliant Blue G-250) and subsequent measurement at $595 \mathrm{~nm}$. Comparison to a standard curve of BSA provides a relative measurement of protein concentration. To compare the protein-to-protein variation of $\mathrm{BCA}$
Protein Assay and Bio-Rad Protein Assay (Bradford method), the concentration of a standard solution of BGG at $1 \mathrm{mg} / \mathrm{mL}$ was determined in triplicate using both assays and a standard curve of BSA.

\subsection{Amino acid analyses}

Additional amino acids analyses (total and free amino acids) were conducted on the same ten samples (Table II). For analysis of total amino acids, $1 \mathrm{~mL}$ of hydrolysis solution $(6 \mathrm{~N} \mathrm{HCl}, 0.1 \%$ phenol, and $500 \mu \mathrm{M}$ norleucine) was added to 3-5 mg (dry weight) of pollen. The tube was put for 1 min under nitrogen to avoid methionine degradation and then incubated for $24 \mathrm{~h}$ at $110{ }^{\circ} \mathrm{C}$. The hydrolysate was evaporated until dryness under vacuum in a boiling bath at $100{ }^{\circ} \mathrm{C}$. Afterwards, $1 \mathrm{~mL}$ of the sodium citrate buffer, $\mathrm{pH} 2.2$, was added into the tube. The sample solution was mixed and poured in an HPLC vial after filtration $(0.2 \mu \mathrm{m})$. Each amino acid was measured separately with an ion exchange chromatograph (Biochrom 20 Plus Amino Acid analyzer). A post-column ninhydrin reaction produced colored derivatives, which was monitored via a UV detector. Free amino acids were extracted from 30 to $50 \mathrm{mg}$ (dry weight) pollen with $200 \mu \mathrm{L}$ of extraction solution $(1 \mathrm{mM}$ norleucine, $0.1 \mathrm{~N} \mathrm{HCl}$, and $2 \%$ thiodiglycol) in an ultrasonic bath for $30 \mathrm{~min}$. Afterwards, $100 \mu \mathrm{L}$ of $15 \%$ dihydrated 5sulfosalicylic acid was added for precipitation of proteins in the ultrasonic bath for $5 \mathrm{~min}$. After centrifugation $(8,120 \times \mathrm{g}$ for $5 \mathrm{~min}$ at room temperature), $250 \mu \mathrm{L}$ of the supernatant was poured into a microcentrifuge tube with a filter $(0.2 \mu \mathrm{m})$. After centrifugation and membrane filtration $(6,710 \times \mathrm{g}$ for $10 \mathrm{~min}$ at room temperature), $100 \mu \mathrm{L}$ of a $\mathrm{pH}$ adjustment solution $(1: 1,1.5 \mathrm{~N} \mathrm{NaOH}$ and $\mathrm{pH} 2.2$ buffer) was added to $240 \mu \mathrm{L}$ of the supernatant before measurement in the amino acid analyzer. For both amino acid extractions, norleucine was used as the internal standard.

\subsection{Data analysis}

We checked the normality of the distributions of protein data by normal QQ plot and Shapiro test ( $P$ values $>0.05$ ). If normal, we performed parametric paired $t$ tests on data to 


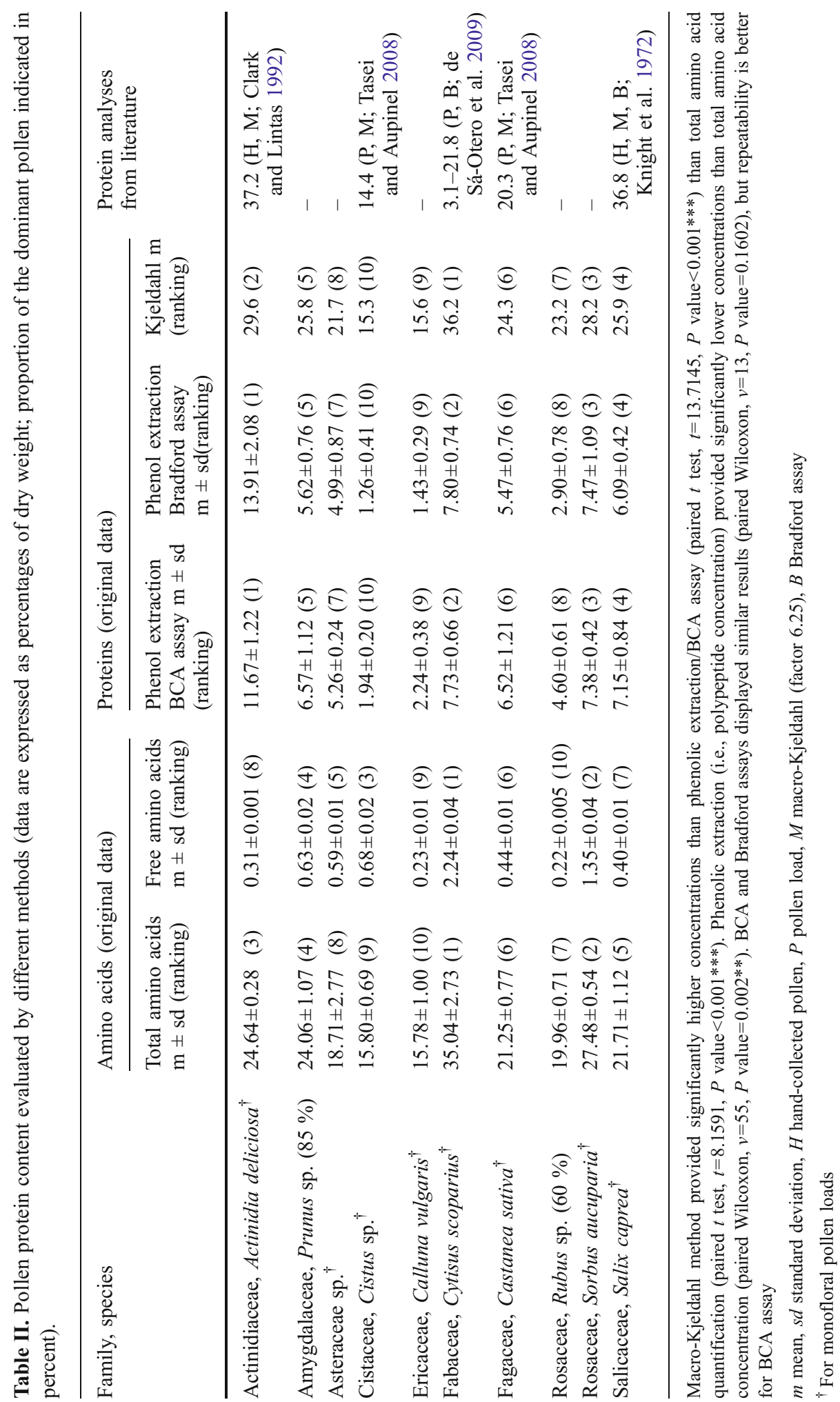


test the null hypothesis of no difference in protein contents. In the absence of normality, we performed a nonparametric equivalent test (paired Wilcoxon). All data analyses were performed in $\mathrm{R}$ version 2.2.1 with SciViews R Console (version 0.9.2).

\section{RESULTS}

\subsection{Efficiency and repeatability of phenolic extraction and BCA quantification}

Phenolic extraction achieves a high polypeptide recovery from the BGG standard with a loss of less than $6 \%$ on average (recovery rate $94.5 \pm 7.1 \%, n=3)$. In contrast, the MALDITOF spectra revealed a loss of the majority of oligopeptides and enrichment in some of them during phenolic extraction.

Almost all pollen grains are fully destroyed during the extraction and remaining grains are too sparse to be counted. Polypeptide content of willow pollen is estimated from 10 to $13 \%$ in the 15 independent aliquots (Table I). The coefficients of variation (CV) of polypeptide levels in the three independently extracted batches range from 5.03 to $7.85 \%$ and highlight the quality of the extraction procedure $(6.08 \%$ on average, Table I). The BCA Protein Assay is also reliable with variation coefficients of the measured polypeptide levels ranging from 1.87 to $15.20 \%$ in all aliquots $(7.42 \%$ on average and only three CV upper than $10 \%$; Table I). Given the limited number of samples investigated, the repeatability of polypeptide extraction and quantification are more than satisfactory. This new method seems therefore to be highly reliable in terms of repeatability and efficiency.

\subsection{Comparison with Bradford and Kjeldahl methods}

The concentration of a standard solution of $1,000 \mu \mathrm{g} / \mathrm{mL}$ BGG is estimated at $716.45 \pm$ $97.07 \mu \mathrm{g} / \mathrm{mL}$ with the Bio-Rad Protein Assay (Bradford method) by using a standard curve of BSA. With BCA Protein Assay and standard curve of BSA, the concentration of the same standard solution is estimated at 1,010.36
$25.02 \mu \mathrm{g} / \mathrm{mL}$, minimizing the bias due to standard protein choice.

The ten pollen species display a large range of polypeptide content from $1.94 \%$ (Cistus sp.) to $11.67 \%$ of dry weight (A. deliciosa) (Table II). While polypeptide quantification and ranking of the ten species are similar between Bradford and BCA assays (paired Wilcoxon, $v=13, P$ value $=$ 0.1602 ) (Table II), the coefficients of variation are greater for Bio-Rad Protein Assay (6.80-32.54 \%) compared to BCA Protein Assay (4.56-18.56 \%) (Table II). The difference between Bio-Rad Protein Assay and BCA Protein Assay is quite variable from $0.07 \%$ of dry weight (C. scoparius) to $2.24 \%$ of dry weight (A. deliciosa) and seems dependent on pollen species avoiding any bias removal.

Protein content based on macro-Kjeldahl method is always higher than polypeptide concentration based on phenolic extraction (paired $t$ test, $t=13.7145, P$ value $<0.001^{* * *}$ ), from three times ( $A$. deliciosa) to eight times (Cistus sp.). Protein contents based on macroKjeldahl are similar to total amino acid values but remain significantly higher, from 1.14 to 1.28 times higher (paired $t$ test, $t=8.1591$, $P$ value $<0.001^{* * *}$ ) (Table II).

The ranking of pollen species according to their total amino acid content is different from the ranking based on polypeptide content (from phenolic extraction) (paired Wilcoxon, $v=55$, $P$ value $\left.=0.002^{* *}\right)$. The variation in free amino acids is demonstrated in Table II going from $0.22 \%$ (Rubus sp.) to $2.24 \%$ (C. scoparius) of lyophilized weight.

\subsection{Polypeptide contents in hand-collected pollen versus pollen loads}

Polypeptide contents of hand-collected pollen differ strongly from $7.60 \%$ (H. annuus) to $24.32 \%$ (A. deliciosa) of lyophilized weight (Table III). Hand-collected pollen samples always contain higher concentrations of polypeptide than their counterpart pollen loads, from twice as much in A. deliciosa, H. annuus, and $I$. glandulifera to four times as much for $H$. helix. On average, polypeptide content differs significantly between hand-collected pollen and pollen 
Table III. Polypeptide content of pollen loads and hand-collected pollen by using phenol extraction and BCA assay (data expressed as percentages of dry weight).

\begin{tabular}{|c|c|c|c|c|}
\hline \multirow[t]{2}{*}{ Family, species } & \multicolumn{3}{|c|}{$\begin{array}{l}\text { Original analyses of polypeptides mean } \pm \mathrm{sd} \\
\text { (ranking) }\end{array}$} & \multirow[t]{2}{*}{$\begin{array}{l}\text { Amino acid and protein } \\
\text { analyses from literature }\end{array}$} \\
\hline & Pollen load (P) & $\begin{array}{l}\text { Hand-collected } \\
\text { pollen }(\mathrm{H})\end{array}$ & $\mathrm{P} / \mathrm{H}$ & \\
\hline Actinidiaceae, Actinidia deliciosa & $11.67 \pm 1.22(1)$ & $21.02 \pm 1.61(2)$ & 0.56 & $\begin{array}{l}37.2(\mathrm{H}, \mathrm{M} \text {; Clark and } \\
\text { Lintas 1992) }\end{array}$ \\
\hline Asteraceae, Aster tripolium & $4.30 \pm 0.49(8)$ & $13.90 \pm 1.77(6)$ & 0.31 & - \\
\hline Asteraceae, Helianthus annuиs & $5.05 \pm 0.88(6)$ & $7.60 \pm 0.94(9)$ & 0.66 & $\begin{array}{l}\text { 30.6 (H, M, B; Hurd } \\
\text { et al. 1980); 13.4 } \\
\text { (P, M; Somerville and } \\
\text { Nicol 2006); } 14.4 \\
\text { (P, M; Tasei and } \\
\text { Aupinel 2008) }\end{array}$ \\
\hline $\begin{array}{l}\text { Balsaminaceae, Impatiens } \\
\text { glandulifera }\end{array}$ & $10.07 \pm 1.23(2)$ & $17.20 \pm 0.73(4)$ & 0.59 & $\begin{array}{l}13.6(3.1)(\mathrm{H}, \mathrm{A} \text {; } \\
\text { Weiner et al. 2010) }\end{array}$ \\
\hline Ericaceae, Calluna vulgaris & $4.75 \pm 0.26(7)$ & $13.37 \pm 0.93(8)$ & 0.36 & - \\
\hline Fabaceae, Cytisus scoparius & $7.73 \pm 0.66(4)$ & $24.32 \pm 2.42(1)$ & 0.32 & $\begin{array}{l}\text { 3.1-21.8 (P, B; de } \\
\text { Sá-Otero et al. 2009) }\end{array}$ \\
\hline Fabaceae, Medicago sativa & $6.62 \pm 0.65(5)$ & $17.71 \pm 1.79(5)$ & 0.37 & $\begin{array}{l}20 \text { (P, M; Standifer } \\
\text { 1967); 20-24 (P, M; } \\
\text { Stace 1996); 16.6 (2.4) } \\
\text { (H, A; Weiner et al. } \\
\text { 2010); 22.5 \% (P, M; } \\
\text { Forcone et al. 2011) }\end{array}$ \\
\hline Hederaceae, Hedera helix & $3.37 \pm 0.14(9)$ & $13.56 \pm 1.37(7)$ & 0.25 & $\begin{array}{l}19.9(5.5)(\mathrm{H}, \mathrm{A} \text {; Weiner } \\
\text { et al. 2010) }\end{array}$ \\
\hline Salicaceae, Salix caprea & $7.16 \pm 0.63(3)$ & $18.42 \pm 2.43(3)$ & 0.39 & $\begin{array}{l}36.8(\mathrm{H}, \mathrm{M}, \mathrm{B} ; \mathrm{Knight} \\
\text { et al. 1972) }\end{array}$ \\
\hline
\end{tabular}

The concentrations are expressed as percentages of dry weight. On average, protein content differs significantly between hand-collected pollen and pollen loads from the same plant species (paired $t$ test, $t=7.7296, P$ value $<0.001 * * *$ )

$m$ mean, $s d$ standard deviation, $H$ hand-collected pollen, $P$ pollen load, $M$ macro-Kjeldahl (factor 6.25), $B$ Bradford assay

loads from a same plant species (paired $t$ test, $t=$ 7.7296, $P$ value $<0.001^{* * *}$ ).

Ranking of plants according to their polypeptide contents is not the same for pollen loads or hand-collected pollen. For example, H. helix could be considered with relatively poor nutritional value based on pollen load values, but its hand-collected pollen shows a polypeptide concentration comparable to the others species analyzed. The change of ranking is also noticeable for C. scoparius (Table III).

\section{DISCUSSION}

\subsection{Advantages of the present method}

Polypeptide concentrations are significantly lower based on our adapted method than protein concentration based on current methods (i.e., Kjeldahl and Bradford assays, total amino acid analyses) (Table II). The polypeptides that we quantified are indeed the strict proteinaceous part (molecular weight $>10,000 \mathrm{Da}$ ) of the other 
estimations. Kjeldahl assays do not distinguish polypeptide nitrogen from non-polypeptide nitrogen sources such as oligopeptides (molecular weight $<10,000 \mathrm{Da}$ ), free amino acids, nucleic acids, or alkaloids, while amino acid analyses do not distinguish polypeptides from oligopeptides and free amino acids (Csonka et al. 1925).

Application of single universal factors is not possible to standardize these different quantifications. The ratio between polypeptides and total amino acids range from 0.13 in Cistus sp. to 0.39 in A. deliciosa. Our results also highlight the great variability of the amount of non amino acid nitrogen that can be a significant part of the total amino acid estimation (e.g., overestimation of $39.95 \%$ in the pollen of $A$. deliciosa by comparing total amino acids and Kjeldahl values) as well as a negligible part (e.g., pollen of C. vulgaris).

Moreover, the combination with BCA assay makes possible to quantify the polypeptides independently of their amino acid composition, reducing the protein-to-protein variation met with the Bradford assay. Typically, polypeptides with low arginine content will be underestimated using Bradford assay (Kruger 2002). Our results confirm this methodological bias. We show that quantifications from Bradford and BCA assays strongly differ in some species (e.g., in Rubus sp. and $C$. vulgaris, Table II). These differences are highly variable preventing the use of a conversion factor.

Another advantage of our method is that polypeptides are preserved allowing further proteomic analyses notably based on mass spectrometry. In the hydrolysis process as in total amino acid analysis, proteins are destroyed. Our method opens new perspectives for research in dietetic studies, in particular to determine the impact of pollen polypeptide type on nitrogen assimilation efficiency (Alaux et al. 2010) or on host plant attractiveness for pollinators (Mayer et al. 2011).

\subsection{Pollen quality and polypeptide contents}

Pollen proteins are digested in the midgut and broken down into their amino acid components that are absorbed (Cohen 2004) while free amino acids can be assimilated immediately by the body (Campos et al. 1997). Therefore, it is to be expected that bees spend more energy in assimilating large proteins than small peptides or free amino acids. A diet containing more oligopeptides than polypeptides could be more easily digested by bees and therefore could be more attractive depending on bee perception and taste (de Brito Sanchez 2011 and references therein). However, polypeptides display several functional roles in insect diets including binding fats, binding flavors, and storage (Cohen 2004). They act as emulsifiers and film formers at interfaces between diet components (Cohen 2004). Polypeptides also influence the diet viscosity and help diets to retain a given shape (Cohen 2004). Moreover, these macromolecules may give the diets greater elasticity or other texture features that may be desirable in some circumstances (Cohen 2004). The link between pollen quality and polypeptide content still needs to be established as previous studies on bee physiology did not separate polypeptide from oligopeptide estimations. The present study shows for the first time the variability of the ratio between polypeptide and oligopeptide contents among pollen from various plant species.

Differences among total amino acid, free amino acids, and polypeptide contents highlight a high concentration of oligopeptides in pollen. Although pollens with high level of total amino acids display a high level of polypeptides (see ranking in Table II), pollen quality cannot be estimated based on polypeptide rates only. Indeed, polypeptide content alone may not adequately reflect the availability and quality of amino acid balance (Standifer 1967). Plants can differ strongly in their balance of free amino acids, essential amino acids, and protein-bound amino acids (Weiner et al. 2010). Polypeptide content is only a part of the amino acids available and two diets containing the same polypeptide content may differ in nutritional value. Growing evidence suggests that amino acid composition determines the amount of pollen required by bees, more than its crude protein content (Nicolson 2011; Höcherl et al. 2012; Nicolson and Human 2013).

Moreover, our results show that polypeptide quantity in honeybee pollen loads is significantly different from polypeptide quantity of handcollected pollen counterparts, probably because of 
the addition of nectar to pollen loads. While Standifer et al. (1980) present very low differences between crude protein of pollen loads and handcollected pollen from almond (Rosaceae, Prunus dulcis), 22.6 and $22.2 \%$, respectively (microKjeldahl method), Roulston et al. (2000) indicate a very high variation for Populus fremontii (Salicaceae), 16 and $43.1 \%$, respectively (microKjeldahl method). This difference in protein/ polypeptide content between pollen loads and hand-collected pollen is often high but quite variable according to the species, so that the bias cannot be removed by a universal correction factor (Roulston et al. 2000). Hand-collected pollen provides therefore more reliable information to evaluate the quality of plant resources. These analyses conducted on floral pollen are even more important to evaluate the polypeptide quality of resources for wild bees that do not make pollen loads or make pollen loads in different moisture.

In conclusion, we advise analyzing the total amino acid and polypeptide contents of handcollected pollen (with BCA quantification) to determine the quality of plant as pollen resource. Current Kjeldahl method provides very crude approximation for samples adulterated with nonprotein nitrogen. Moreover, the method is more complex (i.e., numerous wet chemistry step involved in the analysis) and more expensive (i.e., specific analytical equipment for sample preparation and nitrogen measurement). It also requires large quantity of material as well as safety hazards such as concentrated acids or heavy metal catalysts.

\section{ACKNOWLEDGMENTS}

The authors would like to thank David Morris (Centre of Modern Languages, UMONS) for improving an early version of the manuscript. Thanks to Albert Michez, Azzédine Pinczewski, Caroline Rosier, Isabelle Van de Vreken, and Bernard Vaissière for their kind help during this study, as well as to the human pollen foragers Pierre-Laurent Zerck, Jonathan Sturbois, and Romain Moerman (UMONS). This research was supported by grants from the "Fonds de la Recherche Fondamentale et Collective" (2.4613.10) (Belgium). Maryse Vanderplanck is a Ph.D. student funded by the Belgian Fund for Scientific Research (FNRS).
Protocole standardisé pour évaluer les polypeptides du pollen comme source d'alimention pour les abeilles

Pollen / extraction de polypeptides / Quantification à l'acide bicinchoninique

Ein standardisiertes Protokoll zur Beurteilung von Pollen-Polypeptiden hinsichtlich ihrer Eignung als Bienenfutter

Pollen / Polypeptid-Extraktion / BCA assay / Nährwert

\section{REFERENCES}

Alaux, C., Ducloz, F., Crauser, D., Le Conte, Y. (2010) Diet effects on honeybee immunocompetence. Biol. Lett. 6, 562-565

Alm, J., Ohnmeiss, T.E., Lanza, J., Vriesenga, L. (1990) Preference of cabbage white butterflies and honey bees for nectar that contains amino acids. Oecologia 84, 53-57

Bremner, J.M., Mulvaney, C.S. (1982) Nitrogen-total. In: Page, A.L., Miller, R.H., Keeney, D.R. (eds.) Methods of soil analysis. Part 2. Chemical and Microbiological Properties, pp. 595-624. American Society of Agronomy, Madison

Brodschneider, R., Crailsheim, K. (2010) Nutrition and health in honey bees. Apidologie 41, 278294

Buchmann, S.L. (1986) Vibratile pollination in Solanum and Lycopersicon: a look at pollen chemistry. In: D'Arcy, W.G. (ed.) Solanaceae II: Biology and Systematics, pp. 237-252. Columbia University Press, New York

Campos, M.G., Cunha, A., Markham, K.R. (1997) Beespollen. Composition, properties, and applications. In: Mizrahi, A., Lensky, Y. (eds.) Bee Products: Properties, Applications, and Apitherapy, pp. 93100. Plenum, New York

Clark, C.J., Lintas, C. (1992) Chemical composition of pollen from kiwifruit vines. N. Z. J. Crop Hortic. 20, 337-344

Cohen, A.C. (2004) Insect Diet: Science and Technology. CRC, Boca Raton

Csonka, F.A., Bernton, H.S., Jones, D.B. (1925) Proteins of timothy and orchard grass pollen and their reaction to vernal hay fever. Proc. Soc. Exp. Biol. Med. 23, 14-16

de Brito Sanchez, M.G. (2011) Taste perception in honey bees. Chem. Senses 36(8), 675-692

De Groot, A.P. (1953) Protein and amino acid requirements of the honey bee (Apis mellifera). Physiol. Comp. Ecologia 3, 197-285 
de Sá-Otero, M.D.P., Armesto-Baztan, S., Díaz-Losada, E. (2009) Analysis of protein content in pollen loads produced in north-west Spain. Grana 48, 290-296

Detzel, A., Wink, M. (1993) Attraction, deterrence or intoxication of bees (Apis mellifera) by plant allelochemicals. Chemoecology 4, 8-18

Dobson, H.E.M., Danielson, E.M., Van Wese, I.D. (1999) Pollen odor chemicals as modulators of 534 bumble bee foraging on Rosa rugosa Thunb. (Rosaceae). Plant. Species Biol. 14, 153-166

Feuillet, D., Odoux, J.F., Mateescu, C., Aupinel, P., Lamy, H., Moreau, N., Roucher, L., Souché, T. (2008) Evolution floristique et physico-chimique des pollens récoltés au cours de l'année 2006 sur le site de l'INRA du Magneraud. Bull. Tech. Apic. 35, 20-26

Forcone, A., Aloisi, P.V., Ruppel, S., Munoz, M. (2011) Botanical composition and protein content of pollen collected by Apis mellifera L. in the north-west of Santa Cruz (Argentinean Patagonia). Grana 50, 30-39

Hanley, M.E., Franco, M., Pichon, S., Darvill, B., Goulson, D. (2008) Breeding system, pollinator choice and variation in pollen quality in British herbaceous plants. Funct. Ecol. 22, 592-598

Hartfelder, K, Gentile Bitondi, M.M., Brent, C., GuidugliLazzarini, K.R., Simoes, Z.L.P., Stabentheiner, A., Donato Tanaka, E., Wang, Y. (2013) Standard methods for physiology and biochemistry research in Apis mellifera. J. Apic. Res. 52(1): http://dx.doi.org/ 10.3896/IBRA.1.52.1.06

Herbert, E.W., Shimanuki, H., Caron, D. (1977) Optimum protein levels required by honey bees (Hymenoptera, Apidae) to initiate and maintain brood rearing. Apidologie 8, 141-146

Höcherl, N., Siede, R., Illies, I., Gätschenberger, H., Tautz, J. (2012) Evaluation of the nutritive value of maize for honey bees. J. Insect Physiol. 58, 278-285

Huang, T., Jander, G., de Vos, M. (2011) Non-protein amino acids in plant defense against insect herbivores: representative cases and opportunities for further functional analysis. Phytochemistry 72(13), 1531-1537

Hurd, P.D., LaBerge, W.E., Linsley, E.G. (1980) Principal sunflower bees of North America with emphasis on the southwestern United States (Hymenoptera: Apoidea). Smithson. Contrib. Zool. 310, 1-158

Kitaoka, T.K., Nieh, J.C. (2009) Bumble bee pollen foraging regulation: role of pollen quality, storage levels, and odor. Behav. Ecol. Sociobiol. 63, 501-510

Knight, A.H., Crooke, W.M., Shepherd, H. (1972) Chemical composition of pollen with particular reference to cation exchange capacity and uronic acid content. J. Sci. Food Agric. 23, 263-274

Knox, D.A., Shimanuki, H., Herbert, E.W. (1971) Diet and longevity of adult honey bees. J. Econ. Entomol. 1415-1416

Kruger, N.J. (2002) The Bradford method for protein quantitation. In: Walker, J.M. (ed.) The Protein Protocols Handbook, 2nd edn, pp. 15-22. Humana, New Jersey
Lee, K.P., Cory, J.S., Wilson, K., Raubenheimer, D., Simpson, S.J. (2006) Flexible diet choice offsets protein costs of pathogen resistance in a caterpillar. Proc. R. Soc. B 273, 823-829

Lee, K.P., Simpson, S.J., Wilson, K. (2008) Dietary protein-quality influences melanization and immune function in an insect. Funct. Ecol. 22, 1052-1061

Leonhardt, S.D., Blüthgen, N. (2012) The same, but different: pollen foraging in honeybee and bumblebee colonies. Apidologie 43, 449-464

Mayer, C., Adler, L.S., Armbruster, L., Dafni, A., Eardley, C.D., et al. (2011) Pollination ecology in the 21st century: key questions for future research. J. Poll. Ecol. 3, 8-23

Michener, C.D. (2007) The Bees of the World. The Johns Hopkins University Press, Baltimore

Moore, J.C., DeVries, J.W., Lipp, M., Griffiths, J.C., Abernethy, D.R. (2010) Total protein methods and their potential utility to reduce the risk of food protein adulteration. Compr. Rev. Food Sci. F. 9, 330-357

Nicolson, S.W. (2011) Bee food: the chemistry and nutritional value of nectar, pollen and mixtures of the two. Afr. Zool. 46(2), 197-204

Nicolson, S.W., Human, H. (2013) Chemical composition of the 'low quality' pollen of sunflower (Helianthus annuus, Asteraceae). Apidologie 44, 144-152

Odoux, J.-F., Feuillet, D., Aupinel, P., Loublier, Y., Taseï, J.-N., Mateescu, C. (2012) Territorial biodiversity and consequences on physico-chemical characteristics of pollen collected by honey bee colonies. Apidologie 43, 561-575

Pernal, S.F., Currie, R.W. (2002) Discrimination and preferences for pollen-based cues by foraging honeybees, Apis mellifera L. Anim. Behav. 63(2), 369-390

Quezada-Euan, J.J.G., Lopez-Velasco, A., Perez-Balam, J., Moo-Valle, H., Velazquez-Madrazo, A., et al. (2011) Body size differs in workers produced across time and is associated with variation in the quantity and composition of larval food in Nannotrigona perilampoides (Hymenoptera, Meliponini). Insect. Soc. 58, 31-38

Robertson, A.W., Mountjoy, C., Faulkner, B., Roberts, M., Macnair, M. (1999) Bumblebee selection of Mimulus guttatus flowers: the effects of pollen quality and reward depletion. Ecology 80, 2594-2606

Roulston, T.H., Cane, J.H. (2000) Pollen nutritional content and digestibility for animals. Plant Syst. Evol. 222, 187-209

Roulston, T.H., Cane, J.H. (2002) The effect of pollen protein concentration on body size in the sweat bee Lasioglossum zephyrum (Hymenoptera: Apiformes). Evol. Ecol. 16, 49-65

Roulston, T.H., Cane, J.H., Buchmann, S.L. (2000) What governs protein content of pollen: pollinator preferences, pollen-pistil interaction, or phylogeny? Ecol. Monogr. 70, 617-643

Schmidt, J.O., Hanna, A. (2006) Chemical nature of phagostimulants in pollen attractive to honeybees. J. Insect Behav. 19, 521-532 
Sedivy, C., Muller, A., Dorn, S. (2011) Closely related pollen generalist bees differ in their ability to develop on the same pollen diet: evidence for physiological adaptations to digest pollen. Funct. Ecol. 25, 718-725

Somerville, D.C., Nicol, H.I. (2006) Crude protein and amino acid composition of honey bee-collected pollen pellets from south-east Australia and a note on laboratory disparity. Aust. J. Exp. Agric. 46, 141-149

Stace, P. (1996) Protein content and amino acid profiles of honey bee-collected pollens. Bees ' $n$ trees Consultants, Queensland

Standifer, L.N. (1967) A comparison of the protein quality of pollens for growth-stimulation of the hypopharyngeal glands and longevity of honey bees, Apis mellifera L. (Hymenoptera: Apidae). Insect Soc 14, 415-425

Standifer, L.N., McCaughey, W.F., Dixon, S.E., Gilliam, M., Loper, G.M. (1980) Biochemistry and microbiology of pollen collected by honey bees (Apis mellifera L.) from almond, Prunus dulcis. II.
Protein, amino acids and enzymes. Apidologie 11, 163-171

Tasei, J.N., Aupinel, P. (2008) Nutritive value of 15 single pollens and pollen mixes tested on larvae produced by bumblebee workers (Bombus terrestris, Hymenoptera: Apidae). Apidologie 39, 397-409

Vanderplanck, M., Michez, D., Vancraenenbroeck, S., Lognay, G. (2011) Micro-quantitative method for analysis of sterol levels in honeybees and their pollen loads. Anal. Lett. 44, 1807-1820

Wang, W., Vignani, R., Scali, M., Cresti, M. (2006) A universal and rapid protocol for protein extraction from recalcitrant plant tissues for proteomic analysis. Electrophoresis 27, 2782-2786

Weiner, C.N., Hilpert, A., Werner, M., Linsenmair, K.E., Bluthgen, N. (2010) Pollen amino acids and flower specialisation in solitary bees. Apidologie 41, 476-487

Whitehead, A.T., Larsen, J. (1976) Electrophysiological responses of galeal contact chemoreceptors to selected sugars and electrolytes. J. Insect Physiol. 22, 1609-1616 